
М. В. СЕMEHЮK ${ }^{3}$

КЗ "Обласний перинатальний центр" Рівненської обласної ради ${ }^{1}$

ДВНЗ “Тернопільський державний медичний університет імені І. Я. Горбачевського МОЗ України"2

ТзОВ "ЛОКЕ", Рівне ${ }^{3}$

\title{
Покази до планового хірургічного лікування вагітних при первинному симптомному хронічному захворюванні вен нижніх кінцівок, зовнішніх статевих органів, промежини або в їх поєднанні в умовах короткотермінового перебування в стаціонарі
}

\begin{abstract}
Мета роботи: розробити і впровадити суворо індивідуальні показання до безпечного як для матері, так і дитини, ефективного патогенетичного планового хірургічного лікування вагітних із первинним симптомним хронічним захворюванням вен (ПСХЗВ) в умовах короткотермінового перебування в акушерському стаціонарі (до 72 год за термінологією IAAS).

Матеріали і методи. На базі комунального закладу “Обласний перинатальний центр” Рівненської обласної ради за період 3 початку 2013 р. по перший квартал 2018 р. прооперовано 356 вагітних з ПСХЗВ C2s-C4s,Ep,As,p.Pr (basis CEAP,2002). Показаннями до планового оперативного втручання у 246 вагітних (69,1\%) були наростання явищ хронічної венозної недостатності нижніх кінцівок, зовнішніх статевих органів, промежини не зважаючи на проведену консервативну терапію; у 84 пацієнток (23,6 \%) з метою підготовки пологових шляхів до природних пологів при варикозному розширенні вен зовнішніх статевих органів та промежини, для зменшення ризиків кровотеч при можливому розриві варикозних вузлів та звужуючи показання до хірургічних пологів; у 26 хворих (7,3 \%) за їх бажанням зменшення косметичних проблем, які зумовлені варикозним розширенням вен зовнішніх статевих органів i/або на відкритих частинах нижніх кінцівок. Всім оперованим вагітним виконано дуплексне сканування вен із картографуванням патологічних зон (рефлюкси, варикозні конгломерати), оцінку біофізичного профілю плода (БПП), кардіотокографію (КТГ), вивчення згортальної системи крові, кровотік у маткових, пуповинній, середньомозковій артеріях як до, так і після операції.

Результати досліджень та їх обговорення. Оперативні втручання виконували тільки при згоді вагітних, при відсутності протипоказань до оперативного втручання як з боку соматичного, так і акушерського статусів в умовах акушерського стаціонару. Всі оперативні втручання виконували без премедикації, для знеболення використовували тумесцентну анестезію і хірургічну методику за типом CHIVA при низхідному розвитку ПСХЗВ, а при висхідному - поєднання методик CHIVA i ASVAL. У 100 \% вагітних під час оперативного втручання в післяопераційному періоді порушень соматичного статусу, тонусу матки у вагітних, серцебиття плода (дані КТГ, БПП) не зафіксовано. За суб’єктивною оцінкою вагітними, порушень кількості та якості рухів плода не зазначено, і вони у 98 \% випадків вказали на позитивний клінічний результат хірургічного втручання. Оперовані у II та на початку III триместрів у 85 \% знаходились протягом 24 год, 10 \% - протягом 48 год в умовах стаціонару, після виписували під спостереження акушера-гінеколога за місцем проживання, 5 \% оперованих в кінці III триместру залишались в стаціонарі до пологів.
\end{abstract}

Ключові слова: хірургічне лікування під час вагітності; безпечність оперативного втручання під час вагітності; оцінка больового синдрому; ц-ВАШ шкала.

Постановка проблеми і аналіз останніх досліджень та публікацій. Гестаційний дебют хронічного захворювання вен (ХЗВ за класифікацією CEAP, 2002 р.) нижніх кінцівок промежини, зовнішніх статевих органів спостерігають у 32-80 \% вагітних, які часто вагітніють із короткими інтервалами між вагітностями. Дана патологія становить 5,6 \% від усієї екстрагенітальної патології під час вагітності $[1,2,3,4,6]$.

На думку В. І. Медведя, це - $є$ “вагітність асоційована патологія” і маніфестується ураженням екстрагенітальних органів і систем, що дуже важливо потребує додатково компетенції спеціаліста - не акушера-гінеколога [7].

Однією із причини виникнення і прогресування ХЗВ під час вагітності є послаблювальний ефект прогестерону на гладкі м'язи, що сприяє розширенню вен таза та нижніх кінцівок через механізм варикозної трансформації вен, особливо на фоні уродженного або індукованого дефекту в будові венозної стінки, клапанного апарату в них [8, $9,10,11]$.

Інший провокуючий фактор пов'язаний 3 наростанням загальної гіперволемії у вагітних, паралельно росте кровопостачання вагітної матки починаючи і з 20-22 тижнів вагітності, викликає фізіологічний венозний застій у внутрішніх клубових та венах нижніх кінцівок із наростанням венозної гіпертензії, сповільненням кровотоку в них протягом всієї вагітності, що призводить до розширення стінок вен у системі вищеперерахованих венозних басейнів із неспроможністю венозно- 
го клапанного апарату з виникненням рефлюксів [12]. Значення вертикального i/або горизонтального поверхневого рефлюксу в розвитку варикозного розширення вен нижніх кінцівок не піддається сумніву $[13,14,15,16]$.

Відомо, що варикозна хвороба на початку розвивається в ізольованих сегментах венозної системи, у яких внаслідок генетичної слабкості венозної стінки виникає так звана, на думку авторів, локальна “камера напруги” з ділянками морфологічних змін стінки і більшою мірою їх функціональною (відносною) неспроможністю, сприяє в подальшому прогресуванню захворювання і розвитку ускладнених форм [1, 12, 17].

Саме в таких умовах виникає чи прогресує у 56-89 \% спадково зумовлена недостатність клапанів вен нижніх кінцівок жінки, що в подальшому сприяє їх варикозному розширенню [18, 19, 20, $21,22]$. За даними авторів первинне Х3В, особливо під час вагітності, має схильність до прогресування і в кінцевому результаті може призвести до розвитку тяжких форм проявів захворювання: флебіт, флеботромбозу (10\%), тромбемболій судин (0,6 \%), трофічних виразок нижніх кінцівок (2,3 \%). Частота тромбофлебітів із варикозною хворобою нижніх кінцівок може зустрічається у 20-30 \% вагітних, тоді як у вагітних без варикозного розширення вен нижніх кінцівок не було. Окрім того, дослідники важають, що частота венозних тромбозів під час вагітності в загальній популяції жінок складає в середньому 0,42 \% збільшуючись в післяпологовому періоді до 3,5 \% $[24,25,26]$.

Згідно зі світовим стандартам в Україні основними направленням лікування ХЗВ під час вагітності $є$ консервативна терапія, що включає системну фармакотерапію i/або в поєднанні за показаннями 3 місцевою (топічною) терапією в комплексі з компресійною терапією клас компресії 1-2. Флеботропні препарати, як підтвердили наукові дослідження, не діють ні на варикозні вени, ні на профілактику їх виникнення. Основна їх дія спрямована на зменшення проявів специфічних симптомів, що пов'язані із ХЗВ (набряки, відчуття тяжкості в ногах, свербіж та на больові відчуття по ходу варикозно розширених вен) та на неспецифічні прояви захворювання (парестезії, нічні судоми). Проте вагітним призначати їх виправдано тільки тоді, коли користь від них переважає потенційно негативні реакції [26, 27, 28, 29].

Позитивні результати від застосування флеботропних препаратів спостерігали в 54-76 \% пацієнток [30, 31]. Максимальне зменшення інтенсивності больового синдрому (приблизно на 50 \%) спостерігали в перші 2 місяці лікування. У подальшому ця тенденція менш виражена [32].

Більшість як хірургів, так і акушерів-гінекологів проти операцій в плановому порядку на венозній системі нижніх кінцівок, промежини, зовнішніх статевих органів під час вагітності, відтерміновуючи їі на післяпологовий період і після закінчення грудного вигодовування, а дехто рекомендує взагалі виконувати оперативні втручання жінкам після закінчення репродуктивного віку [33, 34, 36].

Заслуговує на увагу думка Л. І. Романчука i I. М. Маланчина [37], яка виходить із серйозних ускладнень, що супроводжують хронічну венозну хворобу. Тому споглядальна та пасивна тактика ведення таких вагітних видається авторам необгрунтованою, проте й радикальні шляхи лікування під час вагітності невиправдані, особливо 3 перших проявів захворювання. Малей М. І. звернув увагу, що хірургічний метод лікування можливий при неефективності консервативної терапії або через неможливість 3 тих чи інших причин використовувати іï [38].

Згідно з Українським консенсусом з лікування пацієнтів із варикозною хворобою нижніх кінцівок від 2005 р. зазначено, що прогресуючий характер патології на певній стадії іï розвитку є абсолютним показаннями до оперативного лікування варикозної хвороби [49].

Клінічні рекомендації з діагностики та лікування ХЗВ під редакцією В. С. Савельєва від 2013 р. уточнюють і наголошують, що тільки при наявності у пацієнтів рефлюксу крові в поверхневі i/або перфорантні вени, з клінічним класом C2C6 із венозною трансформацією підшкірних вен при прохідності по глибоких венах нижніх кінцівок, таза, нижній порожнистій вені є показаннями до оперативного втручання [39].

Закономірності патогенезу захворювання визначають розуміння того, що на ранніх стадіях захворювання можлива ефективна хірургічна корекція патологічного венозного кровотоку шляхом усунення патологічних рефлюксів із видалення ураженого на даний момент венозного сегмента під час вагітності, може затримати або зупинити процес варикозного переродження [1, 40, 41].

На сучасному етапі вагітні активно беруть участь у виборі тактики лікування, оскільки, окрім клінічних симптомів їх турбують косметичні прояви захворювання на відкритих частинах нижніх кінцівок, промежини та зовнішніх статевих органів, вплив захворювання на якість життя і соціальну активність жінок ставлять питання про більш раннє активне лікування з коротким терміном ре- 
абілітації стабільним позитивним результатом лікування як під час вагітності, пологів та в післяпологовому періодах.

Відносно хірургічного лікування варикозного розширення вен нижніх кінцівок у вагітних в останні роки зустрічаються лишень окремі праці. Так В. В. Воробйов і співавт. [40], К. В. Новіков і співавт. [12, 41] виконують оперативні втручання в плановому порядку тільки при певних формах хронічної варикозної хвороби (сегментарний варикоз нижніх кінцівок, зовнішніх статевих органів, промежини).

Гуртовий Б. Л. і співавт. (1977) [42], Буданов П. В. і співавт. (2008) [4] вважають, що хірургічне лікування показане в тих випадках, коли первинний варикоз супрводжується хронічною венозною недостатністю в поєднанні з ускладненнями у вигляді трофічних розладів.

На думку П. М. Баскакової (2012) [52], хірургічне лікування варикозної хвороби нижніх кінцівок під час вагітності доцільно виконувати при різко вираженій деформації периферичних вен із причини клапанної неспроможності як перфорантних, так і поверхневих вен, коли порушена венозна гемодинаміка становить загрозу до виношування плода.

Стойко Ю. М. [1], Новіков К. В. і співавт. [12, 41] звертають увагу на те, що при оперативному втручанні на ранніх стадіях розвитку ХЗВ можлива ефективна корекція венозної гемодинаміки за рахунок ліквідації вертикального i/або горизонтального рефлюксів.

Окрім того, є цікава думка, що під час вагітності при прогресуючому первинному сегментарному варикозі оперативні втручання можливі і в амбулаторних умовах в терміни вагітності 22-32 тижні [40, 41].

Варіант лікування, що планується, повинен бути зрозумілим для пацієнтки (відомим, безпечним, косметичним, численні переваги над іншими методиками), максимально комфортним і має довготривалий лікувальний ефект із коротким періодом реабілітації [43, 44, 45, 46].

У більшості випадків використовують оперативні методики направлені на покращення венозної гемодинаміки - варіант гемодинамічної корекції порушень венозного кровотоку методикою CHIVA, яка передбачає усунення патологічних рефлюксів, фрагментацію магістралей ВПВ із перерозподілу венозного відтоку на користь недекомпенсованих перфорантних вен, мінімізація операційної травми з видалення варикозно розширених притоків ВПВ i/або МПВ методом міні-флебектомії за Мюллером, кросектомією від адекватності виконання якої в більшості випадків залежить ризик розвитку істинного рецидиву захворювання [1, 47]. Незважаючи на широке використання ендовасулярних методик, які, на жаль, неможливо на даний час використовувати у вагітних з тих чи іншій причин.

Оперативні втручання виконували під місцевим наркозом (місцева інфільтраційна анестезія та її різновиди) $з$ використанням переважно 0,15$0,25 \%$ розчину новокаїну або лідокаїну $[6,48]$. Концентрація місцевого анестетика та об'єм його зменшується на 30 \% внаслідок впливу прогестерону на чутливість нервового волокна до болю [50].

У сучасній літературі $є$ дуже мало даних про результати хірургічної корекції первинної прогресуючої варикозної хвороби нижніх кінцівок, промежини, зовнішніх статевих органів, пахвинного каналу в плановому порядку у вагітних. Частота операційних втручань серед вагітних із ХЗВ становить до $6 \%$ із позитивним результатом у 87 \% 3 них [12, 40, 41].

Вивчивши і проаналізувавши літературні дані вітчизняних і закордонних дослідників, які лікували вагітних із ХЗВ, дійшли висновку, що невирішеним $€$ питання показань до планового хірургічного лікування вагітних із ХЗВ при неефективному консервативному їх лікуванні. Не відображено в роботах підготовку природного шляху до пологів при варикозному розширені вен зовнішніх статевих органів і промежини з метою зменшення ризиків кровотеч із травмованих варикозних вузлів у цих ділянках та частоти хірургічних пологів. Невирішеним $\epsilon$ питанням лікування вагітних із прогресуючим ХЗВ при косметичних дефектах на видимих частинах нижніх кінцівок та зовнішніх статевих органах на прохання вагітних. Маловивчені результати і не має однозначної оцінки безпечності планового хірургічного лікування ПСХЗВ під час вагітності як для вагітної, так і плода, особливо при короткотерміновому перебування (за термінологією IAAS) в акушерському стаціонарі.

Мета роботи: розробити і впровадити строго індивідуальні покази до безпечного як для матері, так і дитини, ефективного патогенетичного планового хірургічного лікування вагітних із ПСХЗВ в умовах короткотермінового перебуванням в акушерському стаціонарі (до 72 год за термінологією IAAS).

Матеріали і методи. Венозну патологію $\mathrm{C}_{25}$ $\mathrm{C}_{4 \mathrm{~s}}, \mathrm{E}_{\mathrm{p},} \mathrm{A}_{\mathrm{s}, \mathrm{p}}, \mathrm{P}_{\mathrm{r}}$ (за класифікацією basis CEAP, $2002 \mathrm{p}$.) виявлено у 895 пацієнток (5, 11 \%) серед 17504 вагітних, що проходили лікування на базі комунального закладу “Обласний перинатальний центр” 
Рівненської обласної ради $з$ початку 2013 р. по другий квартал 2018 року. Вік вагітних - від 19

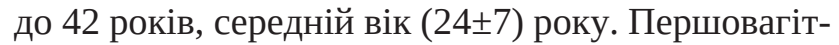
них було 230 (23,12 \%), повторновагітних - 765 (76,88 \%). Для формування строго індивідуальних показів до планового безпечного як для матері, так і дитини хірургічного лікування венозної патології враховували венозну гемодинаміку нижніх кінцівок і таза, розвиток плода, стан вагітної (соматичний і акушерський статус). Венозну гемодинаміку нижніх кінцівок (поверхневої і глибокої венозної системи), клубових вен вивчали у 856 (86,03 \%) вагітних шляхом дуплексного сканування апаратом Lanwind Mirror 11 (Італія) 3 лінійним датчиком частотою 8-10 MHZ згідно 3 розробленим нами протоколом. Оцінювали прохідності по венах, стан клапанного апарату, наявність у них рефлюксів. У 82,5 \% вагітних дослідження проводили в другій половині дня, коли найбільше виражені клінічні прояви захворювання, з обов'язковим проведенням проби Вальсальви в положенні лежачі і стоячи з позначкою дати дослідження. Для встановлення як впливу власне первинного симптомного хронічного захворювання вен на розвиток плода, перебіг вагітності, так і оперативного втручання оцінювали шляхом вивчення тонусу матки і серцебиття плода за допомогою кардіотокографії на апараті Tеamcare V7.43 за допомогою критеріїв Доуза-Редмана, біофізичний профіль плода (БПП) оцінювали в балах з урахуванням рекомендацій Шраєра О. Т. (1991) як найбільш об’єктивна інформація про його життєздатність. Дослідження виконували на УЗД апаратах Esaote MyLab Class C, Philips Austria HD-7. Оцінку згортальної системи крові аналізували за такими параметрами: АЧТЧ, фібриноген, МНО, протромбіновий індекс, тромбоцити крові на апараті Huma Clot Duo Plus (Німечина).

Особливо звертали увагу на стан плацентарного кровообігу за такими показниками, як кровотік по маткових артеріях, артерії пуповини та середньо-мозковій артерії плода, оцінюючи за величиною індексу резистентність, використовуючи УЗД апарат Esaote MyLab Class C. Інтенсивність болю в ранньому післяопераційному періоді (перші 24 год після операції) оцінювали кожні 6 год за допомогою циркадної візуально-аналогової шкали (ц-ВАШ) [51] з інтерпретацією результатів за Jensen M.R. і співавт. [52].

Результати досліджень та їх обговорення. Всіх вагітних (995 пацієнток) з хронічним захворюванням вен (ХЗВ) проконсультував судин- ний хірург за направленням акушера-гінеколога в консультативну поліклініку обласної лікарні або обласного перинатального центру при взятті на облік. Перед судинним хірургом та акушером-гінекологом стояло завдання: чітко встановити етіологію, анатомію, патогенез варикозного розширення вен; розробити тактику лікування, спрямованому на запобігання прогресуванню захворювання, тромбофлеботичні, тромбоемболічні, геморагічні ускладнення; як проводити підготовку пологових шляхів у випадку варикозного розширення вен зовнішніх статевих органів, промежини для безпечних пологів природним шляхом; рекомендувати лікування вагітних при прогресуванні захворювання незважаючи на консервативну терапію, що проводиться чи проводилась; по можливості покращити косметичний стан відкритих частин нижніх кінцівок, зовнішніх статевих органів за бажанням вагітних.

Серед 995 вагітних із ХЗВ після виконаного дуплексного сканування у 895 (89,95 \%) пацієнток виявили первинну хронічну хворобу вен (Ep). Поміж них у 500 (55,86 \%) діагностовано варикозне розширення вен у басейні сафенових вен (великої і/або малої підшкірних вен), варикозне розширення вен у несафеновому басейні (варикозне розширення вен пахового каналу, промежини) виявили у 90 (10,05 \%) вагітних і у 305 (34,07 \%) пацієнток поєднання варикозного розширення вен у басейні сафенових і несафенових вен.

У 196 (21,8 \%) вагітних при першій вагітності ПХЗВ було виявлено у $100 \%$ тільки в басейні сафенових вен, тоді як у 699 (78,1 \%) при повторних вагітностях ця патологія була виявлена в басейні сафенових вен у 294 (42,06 \%) пацієнток, в басейні несафенових вен 90 (12,88 \%) обстежених і поєднанні форми ПХЗВ (сафенових і несафенових вен) діагностовано у 305 (43,63 \%) пацієнток.

Із 895 вагітних із ПХЗВ у 785 (87,7 \%) спостерігали прогресування захворювання з перших тижнів вагітності.

Під запропонованим нами поняттям прогресуюча ПХЗВ (ППХЗВ) нижніх кінцівок, промежини, пахвинного каналу, зовнішніх статевих органів або в поєднанні ми розуміємо як прогресування хронічної венозної недостатності, що проявлялось наростанням клінічних проявів захворювання на всьому протязі терміну вагітності незважаючи на проведення консервативної терапії.

Основними проявами ППХЗВ були симптоми наростання хронічної венозної недостатності: набряки м'яких тканин нижніх кінцівок, промежини та зовнішніх статевих органів у всіх 785 (100 \%) 
пацієнток, тяжкість в нижніх кінцівках, промежині у 202 (25,73 \%) пацієнток, парестезії в ділянці стегон, гомілок і стоп (у вигляді відчуття тепла, повзання мурашок, холоду) у 274 (34,90 \%) пацієнток, судоми в м'язах гомілки i/або стоп у 115 (14,64 \%) пацієнток, свербіж шкірних покривів за ходом варикозно розширених вен, варикозними конгломератами нижніх кінцівок, промежини і зовнішніх статевих органах у 278 (35,4 \%) пацієнток. Всі симптоми прогресували під час вагітності. Також у 61,2 \% вагітних спостерігали прогресування наростання діаметра варикозного розширення вен, поширення їх по довжині кінцівки, формування варикозних конгломератів, що призводило до деформації зовнішніх статевих органів. Наростали і стабільно утримувались набряки м'яких тканин стоп і нижньої третини гомілки, які не минали вранці. Всі вагітні вказували на зниження фізичної і соціальної активності, якості життя з наростанням психоемоційного етапу різного ступеня.

Отримували консервативну терапію 80 \% вагітних із ППХЗВ із перших проявів захворювання в об'ємі, що залежав від триместру вагітності та переносимості, коректного дисциплінованого виконання рекомендованого лікування, 20 \% вагітних утримувались $з$ тих чи інших причин від лікування. Лікування проводили в амбулаторних умовах під контролем лікаря акушера-гінеколога та судинного хірурга. При наявності клінічних проявів ПХЗВ в І триместрі рекомендовано користуватись тільки компресійним трикотажем клас компресії 2, дотримуючись фізичного режиму. 3 II триместру вагітності рекомендували приймати флеботропні препарати загального вживання i/або місцево з обережністю, тільки в разі нагальної потреби в поєднанні з компресійним трикотажем.

У 55 (6,15 \%) пацієнток при лікуванні ППХЗВ спостерігали вплив захворювання на якість життя і соціальну активність жінки, тому вони потребували більш активного лікування з коротким терміном реабілітації та стабільним позитивним результатом лікування як під час вагітності, пологів так і після пологів. Також 25 (2,79 \%) пацієнток потребували корекції венозних косметичних дефектів на шкірних покривах відкритих частинах нижніх кінцівок, зовнішніх статевих органах, промежини.

За результатами проведеної консервативної терапії вагітним із ППХЗВ нижніх кінцівок, промежини, зовнішніх статевих органів, пахвинного каналу виділено 4 групи вагітних. Перша група - 256 (33,76 \%) вагітних, у яких отримано позитивний та тривалий результат від консервативної терапії, друга групу вагітних - 395 (50,32 \%) вагітних, у яких консервативна терапія була неефективна, третя група - 112 (14,27 \%) вагітних, у яких результат від лікування був сумнівним і короткотривалим, четверта група - 22 (2,8 \%) вагітних, яка не проходила курс лікування.

У 529 (67,38 \%) вагітних із ППХЗВ, які не отримали позитивного результату або він був короткотерміновий, сумнівний від консервативної терапії або які не лікувались з тих чи інших міркувань, мало місце прогресування клініки хронічної венозної недостатності та наростання варикозної трансформації вен та їх поширення.

Перед остаточним вибором методу лікування виконували дуплексне сканування глибоких вен нижніх кінцівок, доступних огляду клубових вен, визначали прохідність по них, стан клапанного апарату в них та наявність і поширення по них рефлюксів. Також вивчали венозну гемодинаміку в системі сафенових вен нижніх кінцівок та пахвинного каналу. Спостерігали наявність рефлюксів, їх локалізацію та поширення, "картографуючи”, чітко позначали маркером на шкірних покривах. Причина прогресування клінічних проявів хронічної венозної недостатності при ППХЗВ, за даними дуплексного сканування, зумовлена неспроможністю остіального або приостіального клапанів із поширеним патологічним вертикальним i/або горизонтальними рефлюксами в басейни сафенових і несафенових вен або перетіканнями в цих басейнах із системи клубових, стегнових та гомілкових вен або в поєднанні. Якщо на початку захворювання у 85 \% пацієнток рефлюкс локалізувався в межах стегна при підшкірно-стегновому рефлюксі або в верхній третині гомілки при підшкірно-підколінному рефлюксі або в поєднанні, то при прогресуванні захворювання рефлюкс поширився на всю довжину стегна, гомілку i/або стопу, крім того, спостерігали виражений рефлюкс через підшкірно-стегнове співустя у проксимальні гілки великої підкірної вени, які формують пучок Дельбе. У всіх вагітних за даними дуплексного сканування утримувались патологічні рефлюкси, виявлені до лікування, а у 25,3 \% з'явилися додаткові, в основному на гомілці, протягом проведення консервативної терапії.

Прохідність по глибоких венах нижніх кінцівок, доступних огляду клубових венах збережена, клапанний апарат у них ефективний. Тільки у 23 (4,34 \%) вагітних патологічний рефлюкс поширювався в верхній третині стегнової вени, з басейну внутрішньої клубової вени у вени пахвинного каналу та промежини у 87 (14,7 \%) обстежених. 
Колегіально акушер-гінеколог та судинний хірург, враховуючи акушерський статус вагітної, прояви венозної патології, ризики впливу на вагітну, плід, знеболення, приймали рішення про подальше лікування вагітної. Варіант хірургічного лікування, що планується, повинен бути зрозумілим для пацієнтки (безпечним, мати гарний косметичний ефект переважати над іншими методиками), максимально комфортним, з коротким періодом реабілітації та мати довготривалий лікувальний ефект. Остаточний вибір за методом лікування залишається за вагітною. Виконано аналіз результатів планового хірургічного лікування у 356 (1,5 \%) вагітних з венозною патологією $\mathrm{C}_{2 \mathrm{~s}}{ }^{-}$ $\mathrm{C}_{4 \mathrm{~s},} \mathrm{E}_{\mathrm{p},} \mathrm{A}_{\mathrm{s}, \mathrm{p}} \mathrm{P}_{\mathrm{r}}$ (за класифікацією basis CEAP, 2002 p.), яких було прооперовано в умовах акушерського стаціонару, згідно з розробленими показаннями в терміни вагітності 25-40 тижнів із короткотерміновим післяопераційним періодом (за термінологією IAAS).

Серед пацієнток із первинним хронічним захворюванням вен дали згоду на оперативне втручання 356 (39,78 \%): 246 (69,1 \%) вагітних через прогресування клінічних проявів захворювання, незважаючи на проведену консервативну терапію, 55 (15,45 \%) пацієнток через виражене погіршення якості життя і соціальної активності, косметичних вад, а 84 (23,6 \%) - з метою активної профілактики геморагічних, тромбофлеботичних та тромбемболічних ускладнень та зменшення частоти хірургічних пологів.

Критерії виключення з боку судинного хірурга: в 5 пацієнток через виражений аорто-кавальний i/або синдрому нижньої порожнистої вени, які наростали незважаючи на їх перебування в позі на лівому боці у 15 градусів, в 7 вагітних - виражена психоемоційна неврівноваженість; з боку акушера-гінеколога: - у 6 вагітних тяжка форма пре- або еклампсії, у 2 - тромбофілії, у 4 - виражена фетоплацентарна недостатність; 2 - загроза передчасних пологів.

Оперативні втручання виконували тільки в спеціалізованому акушерському закладі, що є визначальним у оцінці стану матері і плода як до втручання, а в разі потреби виконували підготов- ку матері до оперативного втручання (у 3 випадках гіпохромна анемія вагітних, у 4 загроза передчасних пологів у терміни вагітності 34-35 тижнів). Оптимальним терміном вагітності для виконання оперативного втручання є 30-32 тижні, коли максимально коректна можливість проконтролювати стан плода, стан матері в динаміці.

Прооперовано 356 вагітних: 238 (66,85 \%) в II триместрі вагітності і в III триместрі у 118 (33,15 \%) пацієнток.

Всі оперативні втручання виконували в плановому порядку без премедикації з використанням для знеболення тумесцентну анестезію і хірургічну методику за типом CHIVA при низхідному розвитку ПСХЗВ, а при висхідному - поєднання методик CHIVA і ASVAL.

Оцінку впливу хірургічного лікування розпочали вивчати як за 30 хв до оперативного втручання, так і під час оперативного втручання, аналізуючи зі слів матері її суб’єктивні відчуття про внутрішньоутробну поведінку дитини (кількість і якість рухів) під час операції та через 30 хв після закінчення оперативного втручання, зміни тонусу матки та серцевої діяльності плода за допомогою КТГ. Оперативне втручання із місцевим знеболенням у 100 \% оперованих не вплинуло на акушерський статус вагітної, як під час оперативного втручання, так через 30 хв після його виконання. Тонус матки матері до і після операції - нормотонус за даними кардіотокографії. Кровотік у маткових і артерії пуповини не змінився, зберігався в межах норми (табл. 1).

Показники згортальної системи крові у вагітних із ППХЗВ були в межах норми перед оперативним втручанням. Через 24 год після операції показники згортальної крові не засвідчили тенденції до гіперкоагуляції і тому не було необхідності в застосуванні НМГ у післяопераційний період (табл. 2).

За суб’ єктивною оцінкою болю в ранньому післяопераційному періоді (до 24 год) всі оперовані вказали на наростання інтенсивності болі в перші 6 год після втручання, зі стабілізацією після 12 год з тенденцією до її зменшення протягом спостереження. Після перших 6 год після втручання біль

Таблиця 1. Показники акушерського статусу оперованих

\begin{tabular}{||l|c|c||}
\hline \multicolumn{1}{|c|}{ Показники } & До операції $(\mathrm{n}=356)$ & Після операції $(\mathrm{n}=356)$ \\
\hline Тонус матки & норма & норма \\
\hline Індекс резистентності маткових артерій: & \multicolumn{2}{|c||}{$0,39 \pm 0,1$} \\
\hline права & $0,4 \pm 0,07$ & $0,49 \pm 0,33$ \\
\hline ліва & $0,45 \pm 0,05$ & $0,6 \pm 0,09$ \\
\hline Індекс резистентності пуповинної артерії & $0,48 \pm 0,03$ & \\
\hline
\end{tabular}


Таблиця 2. Показники згортальної системи крові

\begin{tabular}{||l|c|c||}
\hline \multicolumn{1}{|c|}{ Показники } & До операції $(\mathrm{n}=356)$ & Після операції $(\mathrm{n}=356)$ \\
\hline Протромбіновий індекс & $102,1 \pm 11,0$ & $100 \pm 9,2$ \\
\hline Тромбоцити х $10^{9} / л$ & $289,9 \pm 17,4$ & $250 \pm 23,0$ \\
\hline Фібриноген, г/л & $4,5 \pm 0,17$ & $4,2 \pm 0,14$ \\
\hline МНО & $1,0 \pm 0,3$ & $1,2 \pm 0,2$ \\
\hline АЧТЧ, с & $20,37 \pm 0,75$ & $27,13 \pm 0,43$ \\
\hline
\end{tabular}

був у межах 66-74 мм (помірний біль) у $92 \%$ оперованих і не потребував введення знеболювальних препаратів, тільки у 8 \% вагітних біль становив 7589 мм (сильний біль), що потребувало у 98 \% випадків одноразово для тамування болю введення знеболювальних неопійних препаратів, переважно в таблетованній формі. Через 12 год післяопе- раційний біль утримувалась в межах 50-72 мм (помірний біль) у 98,5 \% випадків, у 1,5 \% у межах 72-74 мм (помірний біль) і не потребував введення знеболювальних препаратів. Через 24 год після оперативного втручання у всіх оперованих біль був в межах до 44 мм (легкий біль), який мало впливав на об’єм фізичних навантажень (рис. 1).

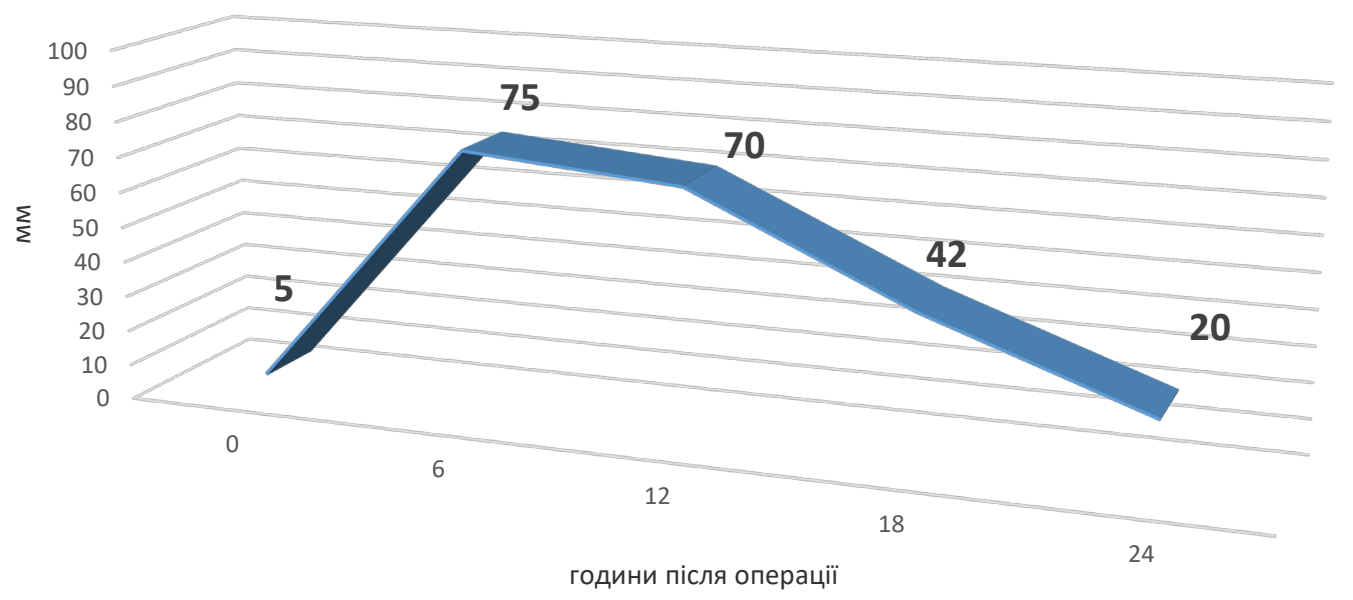

Рис. 1. Динаміка болю в ранньому післяопераційному періоді (24 год після операції).

Стан плода оцінювали в динаміці до і через 24 год після операції, вивчено показники БПП у балах. Сумарну оцінку біофізичного профілю виконували з урахуванням рекомендацій Шраєра О. Т. (1991), оцінювали в балах. Комплексна оцінка БПП дозволила отримати найбільш об'єктивну інформацію про життєздатність плода (табл. 3).

Отримані результати свідчать, що саме захворювання ППХЗВ не вплинуло на показники БПП. Проведене оперативне вручання не привело до погіршення показників БПП. Також за допомогою суб'єктивної оцінки оперованих вагітних оцінку результатів хірургічного лікування проводили через 24 год після операції. Критеріями оцінки були: набряки м'яких тканин, біль за ходом вен, судоми в м'язах оперованих кінцівках, зовнішній вигляд кінцівки. Серед оперованих вагітних біль у післяопераційних ранах не турбував уже через 24-48 год після операції. Біль, що турбував пацієнток до операції за ходом вен на нижніх кінцівках, промежини за суб'єктивною оцінкою оперованих, значно зменшився за інтенсивністю, осо-

Таблиця 3. Біофізичні показники плода

\begin{tabular}{||l|c|c||}
\hline \multicolumn{1}{|c|}{ Показники } & До операції $(\mathrm{n}=356)$ & Після операції $(\mathrm{n}=356)$ \\
\hline Частота серцевих скорочень: & $120 \pm 8$ & $130 \pm 8$ \\
\hline акцелерація & - & - \\
\hline децелерація & - & $14 \pm 1,5$ \\
\hline Частота рухів плода за годину & $12 \pm 3$ & $1,6 \pm 0,1$ \\
\hline $\begin{array}{l}\text { Індекс резистентності } \\
\text { середньомозкової артерії }\end{array}$ & $1,4 \pm 0,05$ & $12 \pm 0,7$ \\
\hline Біофізичний профіль плода (в балах) & $11 \pm 1,5$ & - \\
\hline
\end{tabular}


бливо при фізичних навантаженнях, не турбував у стані спокою. Больові відчуття були в промежині, зовнішніх статевих органах при сидінні, ходьбі та при фізіологічних відправленнях. У всіх оперованих пацієнток спостерігали стійке зменшення набряків м'яких тканин гомілок.

Варикозні конгломерати в ділянці зовнішніх статевих органів, промежини спались у всіх оперованих, не збільшуються при потугах.

Через 2 тижні виконували контрольне дуплексне сканування оперованої кінцівки. Рефлюкси, виявлені до оперативного втручання через стегново-підшкірне, підколіно-підшкірне співустя, перфорантні вени, відсутні, нових не виявлено, стовбури великої i/або малої підшкірних вен та їх гілки, що залишилися помірного наповнення, в підшкірній клітковині гомілок і стоп відсутні або незначні ознаки набряку м’яких тканин.

За суб'єктивною оцінкою стану 96 \% оперованих вагітних вказали на покращення як загального, так і локального статусу, 89,3 \% - покращення якості життя, 90 \% - оперованих - психоемоційного стану та соціальної активності.

При аналізі перебігу вагітності залежно від характеру лікування ПХЗВ встановлено, що серед 529 вагітних, які отримували консервативну терапію, у яких було виражене варикозне розширення вен зовнішніх статевих органів і промежини, у 28 \% випадків пологи проходили через кесарів розтин та у 45 \% випадків пацієнтки з вираженим розширення вен нижніх кінцівок отримували профілактичні дози прямих антикоагулянтих препаратів з метою профілактики тромбофлеботичних, тромбоемболічних ускладнень та у 10 \% випадків діагностовано гострий тромбофлебіт підшкірних вен, що потребувало ургентного оперативного втручання. У групі вагітних із хірургічним лікуванням ППХЗВ показань до кесаревого розтину з причини варикозного розширення зовнішніх статевих органів, промежини не було, вагітні цієї групи антикоагулянтів із профілактичною метою не отримували до, під час та в післяпологовий період (табл. 4).

Таблиця 4. Перебіг вагітності залежно від методів лікування

\begin{tabular}{||l|c|c||}
\hline \multicolumn{1}{|c|}{ Показники } & Оперовані (n=356) & Консервативне лікування (n=529) \\
\hline Кесарів розтин & - & $2 \%$ \\
\hline Гострий тромбофлебіт & - & $1,5 \%$ \\
\hline Використання НМГ & - & За схемою \\
\hline Динаміка захворювання & $2 \%$ & $68 \%$ \\
\hline Прогресування захворювання & $14 \%$ & $10 \%$ \\
\hline Стабільна форма захворювання & $84 \%$ & $22 \%$ \\
\hline Регрес захворювання & & \multicolumn{2}{|c||}{} \\
\hline
\end{tabular}

Оцінивши отримані дані 356 оперованих вагітних, виписали із стаціонару 294 (82,6 \%) вагітних, у яких показники були в межах норми і за їх бажанням через 24 год після оперативного втручання з рекомендаціями під нагляд акушера-гінеколога за місцем проживання за умови:

- повної згоди вагітної;

- можливість самообслугування в післяопераційному періоді;

- готовність дотримуватись звичайного життевого ритму і режиму з максимальним наближенням фізичної (рухової) активності до операційній;

- відсутність необхідності в постійному лікарському спостережені;

- готовність вживати заходи при виникненні ускладнень при перебуванні в домашніх умовах;

- обов'язкова наявність телефонного зв'язку протягом всього післяопераційного періоду;

- наявність стійкого психологічного комфорту в сім’ї пацієнтки.
Залишались в стаціонарі до пологів $62(17,4$ \%) вагітні оперовані наприкінці III триместру.

У 11 (3,28 \%) пацієнток у післяопераційний період спостерігали ускладнення; у 6 (1,79 \%) пацієнток $з$ боку післяопераційних ран у вигляді сератоми, які були ліквідовані, і у 5 (1,49 \%) - тромбофлебіт окремих ізольованих гілок великої підшкірної вени на гомілці і не потребувало додаткового лікування, не обмежувало фізичну активність пацієнток. Ускладнення ліквідовані до пологів.

Висновки. 1. Тісна співпраця акушера-гінеколога і судинного хірурга в спеціалізованому акушерському закладі $є$ визначальною у виборі тактики лікування в плановому порядку ППХЗВ нижніх кінцівок, зовнішніх статевих органів, промежини у вагітних.

2. Одними із основних показань до планового оперативного втручання $€$ : відсутність позитивного результату від консервативної терапії ППХЗВ 
нижніх кінцівок, промежини, зовнішніх статевих органів та пахвинного каналу при прогресуванні наростання клінічних проявів захворювання; косметичних дефіцитів зовнішніх статевих органів та на відкритих частинах нижніх кінцівок; підготовка пологового шляху для безпечного проведення пологів природним шляхом.

3. Оперативне втручання проведено в плановому порядку в спеціалізованому акушерському закладі внаслідок ППХЗВ за строго індивідуаль-

\section{СПИСОК ЛІТЕРАТУРИ}

1. Стойко Ю. М. Варикозная болезнь / Ю. М. Стойко. - СПб. : ВМедА,1992. - 21 с.

2. Шехтман М. М. Руководство по экстрагенитальной патологии у беременных / М. М. Шехтман. - М. : Триада-Х, 2003. - 816 с.

3. Danilenko-Dixon D. R. Risk factors for deep vein thrombosis and pulmonary embolism during pregnancy or post partum a population based case - control study / D. R. Danilenko-Dixon, J. A. Heit, M. D. Silverstein // Am. J. Obstet. Gynecol. - 2001. Vol.184, No.2. - P. 104-110.

4. Буданов П. В. Особенности профилактики и лечения варикозной болезни вен у беременных / П. В. Буданов, В. А. Лебедев // Трудный пациент. - 2008. - С. 28-31.

5. Рогова О. М. Особливості стану імунної системи здорових породілей залежно від способу розродження / О. М. Рогова // ПАГ - 2005. - № 5. - С. 70-74.

6. Delaney A. G. Anesthesia in the pregnancy woman / A. G. Delaney // Clin. Obstet. Gynecology. - 1983. - P. 246-248.

7. Медведь В. И. Беременность-ассоциированная патология / В. И. Медведь // Жіночий лікар. - 2012. - № 2. - С. 8-14.

8. Sansilvestri-Morel P. Chronic venous insufficiency; Dysregulation of Collagen Synthesis / P. Sansilvestri-Morel // Angiology. - 2003. - Vol. 54, Suppl. 1. - P. 13-18.

9. Pappas P. Pathology and cellular physiology of chronic venous insufficiency / P. Pappas, W. Duran, R. Hobson. // Handbook of venous disorders. Guidelines of American Venous Forum. London-New York-New-Deli: Arnold, 2001. - P. 58-67.

10 Pistorius M. Chronic venous insufficiency; The genetic influence / M. Pistorius // Angiology. - 2003. - Vol. 54, Suppl. 1. - P. 5-12.

11. Jawien A. The influence of environmental factors in chronic venous insufficiency // Angiology. - 2003. - Vol. 54, Suppl. 1. P. 19-31.

12. Хирургическое лечение варикозной болезни у беременных / К. В. Новиков, В. В. Воробьев, В. Г. Абашин [и др.] // Материалы III съезда амбулаторных хирургов РФ // Амбулаторна хирургия. - 2009. - № 3-4 (35-36). - С. 135-136.

13. Porto L. Connective tissue accumulation in the muscle layer in normal and varicose saphenous veins / L. Porto // Angiology. 1995. - Vol. 46, No. 3. - P. 243-249.

14. Stucker M. The hystomorphologic changes at the saphenofemoral junction in varicosis of the greater saphenous vein / V. Stucker // Vasa. - 2000. - Vol. 29, No. 1. - P. 41-46.

15. Endovenous laser ablation(EVLA)of great saphenous vein to abolish >paradoxical reflux>in the Giacomini vein; a shot report / N. S. Treivacumar, D. Dellagrammaticas, A. I. Mavor, M. J. Gough // Eur. J. Vasc. Endovasc. Surg. - 2007. - Vol. 34 (2). - P. 229-231.

16. Oguzkurt l. Ultrasonographic anatomy of the lower extremity superficial veins / L. Oguzkurt // Diagn. Interv. Radiol. - 2012. Vol. 18 (4). - P. 423-430. ними показаннями з врахуванням стану вагітної, плода, венозної гемодинаміки у 100 \% є безпечним для матері і плода за даними об'єктивного обстеження, з позитивним у $97 \%$ оперованих клінічним результатом за суб'єктивною оцінкою пацієнток; завдання судинного хірурга на сьогодні довести як акушерам-гінекологам, так і більшості хірургів безпечну можливість як для матері, так і плода, з позитивним клінічним результатом для матері хірургічного лікування ППХЗВ.

17. Новиков К. В. Хирургическое лечение варикозной болезни вен нижних конечностей у беременных / К. В. Новиков // Амбулаторная хирургия. - 2001. - № 2 (2). - С. 37-38.

18. Bauersachs J. Pathophysiology of chronic venous insufficiency / J. Bauersachs, I. Fleming, R. Busse // Phlebolgy. - 1996. Vol. 11. - P. 16-22.

19. Запорожан В. М. Акушерство і гінекологія / В. М. Запорожан, М. Р. Цегельський. - К. : Здоров’я, 1996. - С. 240.

20. Кулаков В. И. Заболевания венозной системы нижних конечностей у беременных, рожениц и родильниц / В. И. Кулаков, Е. А. Чернуха, А. В. Мурашко // Вестн. Рос. ассоц. акуш.гин. - 2000. - № 4. - С. 64-70.

21. Берган Дж. Дж. Хроническая венозная недостаточность / Дж. Дж. Берган //Ангиол. исосуд. хир. - 1995. - № 3. - С. 57 59.

22. Lenkovic M. Effect of progesterone and pregnancy on the development of varicose veins / M. Lenkovic, F. Carbajal, Gruber [et al.] // Acta Dermatovenerol. Croat. - 2009. - Vol. 7, No. 4. P. 263-267.

23. Мозес В. Г. Варикозное расширение вен малого таза у женщин в основные возростно-биологические периоды жизни : автореф. дисс. на соискание научн. степени канд. мед. наук / В. Г. Мозес. - Томск, 2006. - 21 с.

24. Мурашко А. В. Етиология и патогенез хронической венозной недостаточности при беременности / А. В. Мурашко // Проблемы беременности. - 2000. - № 2. - С. 16-21.

25. Ведение беременности и родов при венозных тромбемболических осложнениях / О. В. Макаров, А. И. Кириенко, Т. А. Краснова [и др.] // Вест. Рос. ассоц. акуш.-гин. - 1998. № 2. - С. 115-122.

26. Медведь В. И. Венозные осложнения у беременных / В. И. Медведь, В. А. Бенюк, С. Д. Коваль // Медицинские аспекты здоровья женщины. - № 7 (35). - 2010. - С. 29 33.

27. Медведь В. І. Топічна терапія варикозної хвороби та хронічної венозної недостатності у вагітних / В. І. Медведь, О. О. Данилків // Репродуктивное здоровье женщины. - 2007. - № 5. - С. 62-64.

28. Савельев В. С. Современные направления в хирургическом лечении хронической венозной недостаточности / В. С. Савельев // Флеболимфология. -1996. - № 1. - С. 5.

29. Профілактика ускладнень варикозної хвороби у породілей / В. О. Бенюк, В. І. Медведь, Т. Р. Никонюк, С. Д. Коваль // Здоровье женщины. - № 8(54). - 2010. - С. 84-87.

30. Vanscheidt W. Guidelines for testing drugs for chronic venous insufficiency / W. Vanscheidt, H. Heidrich, M. Junger, E. Rabe // VASA. -2000. - Vol. 29. - P. 274-278.

31. Steins A. Physical therapy in patients with chronic venous insufficiency / A. Steins, M. Junger // Phlebologie. - 2000. Vol. 29. - P. 48-53. 
32. Analysis of the various procedures used in great saphenous vein surgery in the Czech Republic and benefit of Daflon $500 \mathrm{mg}$ on postoperative symptoms / L. Veverkova, V. Jedika, J. Wechsler [et al.] // Phlebolymphology. - 2006. - Vol. 13. - P. 195-201.

33. Krasinski Z. Pregnancy as a risk factor in development of varicose veins in women / Z. Krasinski, S. Sajdak, R. Staniszewski [et al.] // Gynecol. Pol. - 2006. - Vol. 77 (6). - P. 441-449.

34. Артымчук Н. В. Варикозное расширение вен органов малого таза / Н. В. Артымчук // Рос. вест. акуш.-гин. - 2007. № 6. - С. 74-77.

35. Швальб П. Г. Вопросы ангиологии сосудистой и оперативной хирургии / П. Швальб. - Рязань, 2005. - С. 3.

36. Резниченко Г. И. Профилактика тромбоэмболических осложнений у беременных группы риска / Г. И. Резниченко, И. А. Антонюк // Тромбози в клінічній практиці: профілактика, діагностика, лікування : матеріали 1 україн. конф. - К. 2004. - C. 150-152.

37. Романчук Л. Профілактика ускладнень хронічної венозної недостатності у вагітних / Л. I Романчук, І. М. Маланчин // Здоровье женщины. - № 3(39). - 2009. - С. 70-73.

38. Малей М. Хронічна венозна недостатність в зоні ризику / И. Малей // Медицинские аспекты здоровья женщины. 2013. - № 4(68). - С. 46-49.

39. Российские клинические рекомендации по диагностике и лечению хронических заболеваний вен / Председ. В. С. Савельев // Флебология. - 2013. - Т. 2, вып. 2.

40. Хирургическое лечение варикозной болезни у беременных / В. В. Воробьев, В. Г. Абашин, И. И. Бутило, В. В. Петров // Материалы 11 съезда амбулаторных хирургов РФ // Амбулаторная хирургия. - № 3-4(35-36). - 2009.

41. Новиков К. В. Хирургическое лечение варикозной болезни вен нижних конечностей у беременных / К. В. Новиков // Амбулаторная хирургия. -2001. - № 2(2). - С. 37-38.

42. Гуртовой Б. Л. Варикозное расширение вен у беременных / Б. Л. Гуртовой, 3. П. Гращенкова // Акушерство и гинекология. - № 5. - 1977. - С. 61-63.

43. Крылов А. Ю. Современные тенденции и прогнозирование результатов лечения больных с неосложненными форма-

\section{REFERENCES}

1. Stoyko, Yu.M. (1992). Varikoznaya bolezn [Varicose disease]. Saint-Petersburg: VMedA [in Russian].

2. Shekhtman, M.M. (2003). Rukovodstvo po ekstragenitalnoy patologii u beremennykh [Manual on extragenital pathology in pregnant women]. Moscow: Triada-KH [in Russian].

3. Danilenko-Dikson, D.R. (2001). Risk factors for deep vein thrombosis and pulmonary embolism during pregnancy or post partum a population based case-control study. Am. J. Obstet. Gynecol., 84 (2), 104-110.

4. Budanov, P.V. (2008). Osobennosti profilaktiki i lecheniya varikoznoy bolezni ven u beremennykh [Features of prevention and treatment of varicose veins in pregnant women]. Trudnyy patsiyent - Hard Patient, 28-31 [in Russian].

5. Rohova, O.M. (2005). Osoblyvosti stanu imunnoi systemy zdorovykh porodilei zalezhno vid sposobu rozrodzhennia [Features of the state of the immune system of healthy pregnant women depending on the method of delivery]. $P A H, 5,70-74$ [in Russian].

6. Delani, A.G. (1983). Anesthesia in the pregnancy woman. Clin. Obstet. Gynecology, 246-248 [in Russian].

7. Medved, V.I. (2012). Beremennost-assotsiirovannaya patologiya [Pregnancy-associated pathology]. Zhinochyi likar Women's Doctor, 2, 8-14 [in Russian]. ми варикозной болезни нижних конечностей / А. Ю. Крылов, А. М Шулудко, С. Е. Хмырова // Флебология. - 2008. - № 2. - C. $37-45$

44. Недостаточность перфорантных вен: критерии и частота выявления / И. А. Золотухин, В. Ю. Богачев, А. Н. Кузнецов, А. И. Кириенко // Флебология. - 2008. - Т. 2. - № 1. - С. 21-26.

45. Perrin М. Варикозная болезнь нижних конечностей: эндовазальная лазерная и радиочастотная коагуляция. Обзор современной литературы / M.Perrin // Флебология. Международный дайджест. - 2004. - № 7. - С. 39.

46. Merchant R. Factors affecting the risk of deep venous occlusion after ultrasound-guided sclerotherapy for varicose veins / R. Merchant, D. Jolley // European J. Vasc. and Endovasc. Surg. - 2008. - Vol. 36, No. 5. - P. 602-605.

47. Villavicencio L. Хирургическое лечение первичного варикозного расширения вен нижних конечностей: прошлое и настоящее / L .Villavicencio // Флеболимфология. - 2002. - № 5. - С. 3-11.

48. Нисвандер К. Акушерство : справочник Калифорнийского университета / К. Нисвандер, Г. Лейзерович, А. Еванс. М. : “Практика”, 1999. - С. 318-347.

49. Український Консенсус з лікування пацієнтів з варикозною хворобою нижніх кінцівок. - Київ, 2005. - С. 19.

50. Charles P. Анестезия у беременных с неакушерськой патологией. / P. Charles, M. D. Gibbs // Медицина неотложных состояний. - No. 4 (17). - 2008. - Р. 34-40.

51. Астахов В. А. Модификация визуально-аналоговой шкалы для оценки болевого синдрома после обширных абдоминальных операций // В. А. Астахов, С. В. Свиридо, А. А. Малышев // Региональная анестезия и лечение острой боли. 2014. - T. VII, № 1. - C. 26-30.

52. Jensen M. P. Interpretation of visual analog scale ratings and change scores. A reanalysis of two clinical trials of postoperative pain / M. P. Jensen, C. Chen, F. M. Brugger // J. Pain. - 2003. Vol. 4 (7). - P. 407-414.

53. Баскакова П. М. Патологічне і оперативне акушерство / За ред. П. М. Баскакова. - Київ : ВСВ “Медицина”, 2012.

8. Sansilvestri-Morel, P. (2003). Chronic venous insufficiency; Dysregulation of collagen synthesis. Angiology, 54 (1), 13-18.

9. Papas, P. (2011). Pathology and cellular physiology of chronic venous insufficiency. London-New-York-New-Deli: Arnold [in Russian].

10. Pistorius, M. (2003). Chronic venous insufficiency; The Genetic Influence. Angiology, 54 (1), 5-12 [in Russian].

11. Jawien, A. (2003). Vliyaniye faktorov okruzhayushchey sredy pri khronicheskoy venoznoy nedostatochnosti [The influence of environmental factors in chronic venous insufficiency]. Angiology, 54 (1), 19-31 [in Russian].

12. (2009). Khirurgicheskoye lecheniye varikoznoy bolezni u beremennykh [Surgical treatment of varicose veins in pregnant women]. Materialy III syezda ambulatornykh khirurgov RF - Materials of Congress III of Ambulatory Surgeons. Ambulatornaya khirurgiya - Ambulatory Surgery, 3-4 (35-36), 135-136 [in Russian].

13. Porto, L. (1995). Connective tissue accumulation in the muscle layer in normal and varicose saphenous veins. Angiology, 46 (3), 243-249.

14. Stucker, M. (2000). The hystomorphologic changes at the saphenofemoral junction in varicosis of the greater saphenous vein. Vasa, 29 (1), 41-46 [in Russian]. 
15. Treivacumar, N.S. (2007). [Endovenous laser ablation (EVLA) of great saphenous vein to abolish paradoxical reflux in the Giacomini vein; a shot report]. Endovasc. Surg., 34 (2), 229231 [in Russian].

16. Oguzkurt, L. (2012). Ultrasonographic anatomy of the lower extremity superficial veins. Diagn. Interv. Radiol., 18 (4), 423430 [in Russian].

17. Novikov, K.V. (2001). Khirurgicheskoye lecheniye varikoznoy bolezni ven nizhnikh konechnostey u beremennykh [Surgical treatment of varicose veins of the lower extremities in pregnant women]. Ambulatornaya khirurgiya - Ambulatory Surgery, 2 (2), 37-38 [in Russian].

18. Bauersachs, J. (1996). Pathophysiology of chronic venous insufficiency. Phlebolgy, 11, 16-22 [in Russian].

19. Zaporozhan, V.M., \& Tsehelskyi, M.R. (1996). Akusherstvo i ginekologiya [Obstetrics and gynecology]. Kyiv: Zdorovia [in Russian].

20. Kulakov, V.I. (2000). Zabolevaniya venoznoy sistemy nizhnikh konechnostey u beremennykh, rozhenits i rodilnits [Diseases of the venous system of the lower extremities in pregnant women, parturient women and puerperas]. Vestn. Ros. ass. akush.-gin. - Herald of Russian Association of Obstetricians Gynecologists, 4, 64-70 [in Russian].

21. Bergan, Dzh.Dzh. (1995). Khronicheskaya venoznaya nedostatochnost [Chronic venous insufficiency]. Angiol. i sosud. khir. - Angiology and Vessels of Surgery, 3, 57-59 [in Russian].

22. Lenkovic, M. (2009). Effect of progesterone and pregnancy on the development of varicose veins. Acta Dermatovenerol. Croat, 7 (4), 263-267 [in Russian].

23. Mozes, V.G. (2006). Varikoznoye rasshireniye ven malogo taza $\mathrm{u}$ zhenshchin $\mathrm{v}$ osnovnykh vozrostno-biologicheskikh periodakh zhizni [Varicose veins of small pelvis in women in the main age-biological periods of life]. Candidate's Extended abstract. Tomsk. 21 p. [in Russian].

24. Murashko, A.V. (2000). Etiologiya i patogenez khronicheskoy venoznoy nedostatochnosti pri beremennosti [Etiology and pathogenesis of chronic venous insufficiency during pregnancy]. Problemy beremennosti - Problems of Pregnancy, 2, 16-21 [in Russian].

25. Makarov, O.V., Kiriyenko, A.I., \& Krasnova, T.A. (1998). Vedeniye beremennosti i rodov pri venoznykh trombembolicheskikh oslozhneniyakh [Management of pregnancy and childbirth when venous thromboembolic complications]. Vest. Ros. assots. akush.-gin. - Herald of Russian Association of Obstetricians Gynecologists, 2, 115-122 [in Russian].

26. Medved, V.I. (2010). Venoznyye oslozhneniya u beremennykh [Venous complications in pregnant women]. Meditsinskiye aspekty zdorovya zhenshchiny - Medical Aspects of Woman's Health, 7 (35), 29-33 [in Russian].

27. Medved, V.I. (2007). Topichna terapiia varykoznoi khvoroby ta khronichnoi venoznoi nedostatnosti u vagitnykh [Topical therapy of varicose veins and chronic venous insufficiency in pregnant women]. Reproduktivnoye zdorovye zhenshchiny Reproductive Woman's Health, 5, 62-64 [in Russian].

28. Savelyev, V.S. (1996). Sovremennyye napravleniya v khirurgicheskom lechenii khronicheskoy venoznoy nedostatochnosti [Modern trends in the surgical treatment of chronic venous insufficiency]. Flebolimfologiya - Phlebilimphology, 1, 5 [in Russian]. 29. Beniuk, V.O. (2010). Profilaktyka uskladnen varykoznoi khvoroby u porodilei [Prevention of complications of varicose veins in pregnant women]. Zdorovye zhenshchiny - Woman's Health, 8 (54), 84-87 [in Russian].

30. Vanscheidt, W., Heidrich, H., Junger, M., \& Rabe, E. (2000). Guidelines for testing drugs for chronic venous insufficiency. VASA, 29, 274-278.
31. Steins, A., \& Junger, M. (2000). Physical therapy in patients with chronic venous insufficiency. Phlebology, 29, 48-53.

32. Veverkova, L., Jedika, V., \& Wechsler, J. (2006). Analysis of the various procedures used in great saphenous vein surgery in the Czech Republic and benefit of Daflon $500 \mathrm{mg}$ on postoperative symptoms. Phlebolymphology, 13, 195-201 [in Russian]. 33. Krasinski, Z. (2006). Pregnancy as a risk factor in development of varicose veins in women. Gynecol. Pol., 77 (6), 441-449 [in Russian].

34. Artymchuk, N.V. (2007). Varikoznoye rasshereniye ven organov malogo taza [Varicose veins of the pelvic organs]. Vest. Ros. assots. akush.-gin. - Herald of Russian Association of Obstetricians Gynecologists, 6, $74-77$ [in Russian].

35. Shvalb, P.G. (2005). Voprosy angiologii sosudistoy $i$ operativnoy khirurgii [Questions of angiology of vascular and operative surgery]. Ryazan [in Russian].

36. Reznichenko, G.I. (2004). Predotvrashcheniye tromboembolicheskikh oslozhneniy u beremennykh zhenshchin $\mathrm{v}$ gruppe riska [Prevention of thromboembolic complications in pregnant women at risk group]. Tromboz $v$ klinicheskoy praktike: profilaktika, diagnostika i lecheniye. Materialy 1-y Ukrainskoy konferentsii - Thrombosis in Clinical Pactice: Prevention, Diagnostics, Treatment: Materials of the Ukrainian Conference 1. Kyiv. (pp. 150-152) [in Russian].

37. Romanchuk, L. (2009). Profilaktyka uskladnen khronichnoi venoznoi nedostatnosti u vahitnykh [Prevention of complications of chronic venous insufficiency in pregnant women]. Zdorovye zhenshchiny - Woman's Health, 3 (39) 70-73 [in Ukrainian].

38. Malei, M. (2013). Khronichna venozna nedostatnist v zoni ryzyku [Chronic venous insufficiency in the risk area]. Meditsinskiye aspekty zdorovya zhenshchiny - Mediacal Aspects of Women's Health, 4 (68), 46-49 [in Ukrainian.]

39. Savelyev, V.S. (2013). Rossiyskiye klinicheskiye rekomendatsii po diagnostike i lecheniyu khronicheskikh zabolevaniy ven Russian clinical recommendations for the diagnosis and treatment of chronic venous diseases]. Flebologiya - Phlebology, 2 (2), [in Russian].

40. Vorobyev, V.V., Abashin, V.G., Butilo, I.I., \& Petrov, V.V. (2009). Khirurgicheskoye lecheniye varikoznykh ven beremennykh zhenshchin [Surgical treatment of varicose veins in pregnant women]. Mat. 11-go syezda ambulatornykh khirurgov $R F$ - Materials of the 11th Congress of Outpatient Surgeons of the Russian Federation. Ambulatornaya khirurgiya - Ambulatory Surgery, 3-4, 35-36 [in Russian].

41. Novikov, K.V. (2001). Khirurgicheskoye lecheniye varikoznykh ven nizhnikh konechnostey u beremennykh zhenshchin [Surgical treatment of varicose veins of lower extremities in pregnant women]. Ambulatornaya khirurgiya Ambulatory Surgery, 2 (2), 37-38 [in Russian].

42. Gurtovoy, B.L. (1977). Varikoznoye rasshireniye ven u beremennykh zhenshchin [Varicose veins in pregnant women]. Akusherstvo i ginekologiya - Obstetrics and Gynecology, 5, 6163 [in Russian].

43. Krylov, A.Yu. Sovremennyye tendentsii i prognozy rezultatov lecheniya patsiyentov s neoslozhnennymi formami varikoznogo zabolevaniya nizhnikh konechnostey [Modern tendencies and predictions of the results of treatment of patients with uncomplicated forms of varicose disease of the lower extremities]. Flebologiya - Phlebology, 2, 37-45 [in Russian].

44. Zolotukhin, I.A. (2008). Neispravnost perforiruyushchikh zhil: kriterii i chastota obnaruzheniya [Failure of perforating veins: criteria and frequency of detection]. Flebologiya - Phlebology, 2 (1), 21-26 [in Russian].

45. Perrin, M. Varikoznaya bolezn nizhnikh konechnostey: endovazalnaya lazernaya $\mathrm{i}$ radiochastotnaya koagulyatsiya. 
Obzor sovremennoy literatury [Varicose disease of the lower extremities: endovasal laser and radiofrequency coagulation. Review of modern literature]. Flebologiya. Mezhdunarodnyy daydzhest - Phlebology. International Digest, 7, 39 [in Russian]. 46. Merchant, R. \& Jolley, D. (2008). Factors affecting the risk of deep venous occlusion after ultrasound-guided sclerotherapy for varicose veins. European J. Vasc. and Endovasc. Surg., 36 (5), 602-605.

47. Villavicencio, L. (2002). Khirurgicheskoye lecheniye pervichnykh varikoznykh ven nizhnikh konechnostey: proshloye i nastoyashcheye [Surgical treatment of primary varicose veins of the lower extremities: past and present]. Flebolimfologiya Phlebolomphology, 155, 3-11 [in Russian].

48. Nisvander, K., Leyzerovich, G., \& Evans, A. (1999). Akusherstvo: Spravochnik Kaliforniyskogo universiteta [Obstetrics: Directory of the University of California]. Moscow: "Praktika” [in Russian].

49. (2005). Ukrainskyi konsensus $\mathrm{z}$ likuvannia patsiientiv z varykoznoiu khvoroboiu nyzhnikh kintsivok [Ukrainian
Consensus on the treatment of patients with varicose bone disorders]. [in Ukrainian].

50. Charles, P. (2008). Anesteziya u beremennykh s akusherskoy patologiyey [Anesthesia in pregnant women with obstetric pathology]. Meditsina neotlozhnykh sostoyaniy - Medicine of Emergency, 4 (17), 34-40 [in Russian].

51. Astakhov, V.A., Svirodo, S.V., Malyshev, A.A. (2014). Modifikatsiya vizualnoy analogovoy shkaly dlya otsenki bolevogo sindroma posle obshirnykh operatsiy na bryushnoy polosti [Modification of the visual analog scale to evaluate the pain syndrome after extensive abdominal operations]. Regionalnaya anesteziya i lecheniye ostroy boli - Regional Anesthesia and Treatment of Acute Pain, 11 (1), 26-30 [in Russian].

52. Jensen, M.P., Chen, C., \& Brugger, F.M. (2003). Interpretation of visual analog scale ratings and change scores. A reanalysis of two clinical trials of postoperative pain. J. Pain, 4 (7), 407-414.

53. Baskakova, P.M. (Ed.). (2012). Patolohichne i operatyve akusherstvo [Pathological and operational obstetrics]. Kyiv: "Medytsyna” [in Russian].

Отримано 11.04.2018

Електронна адреса для листування: kisil2016@ukr.net

\title{
INDICATIONS TO PLANNED SURGICAL TREATMENT OF PREGNANT WOMEN WITH PRIMARY SYMPTOMATIC CHRONIC DISEASE OF THE VEINS OF THE LOWER EXTREMITIES, THE EXTERNAL GENITALIA, THE PERINEUM OR IN THEIR COMBINATION IN A SHORT-TERM STAY IN A HOSPITAL
}

\begin{abstract}
The aim of the work: to develop and implement strictly individualized indications for safe, both for mother and child, effective, pathogenic planned surgical treatment of pregnant women with primary symptomatic chronic vein disease (PSCVD) in a short-term stay in an obstetric hospital (up to 72 hours by IAAS terminology).

Materials and Methods. On the basis of the Public Facility "Regional Perinatal Center" of the Rivne Regional Council for the period from the beginning of 2013 to the first quarter of 2018, 256 pregnant women with PSCVD C2s-C4s,Ep,As,p.Pr (basis CEAP, 2002) were operated. Indications to planned surgical intervention are the following: 196 pregnant women $(76.56 \%)$ - growth of chronic venous insufficiency of the lower extremities, the external genitalia, the perineum despite conservative therapy; in 34 patients (13.28 \%) with the aim of preparing the maternal passages for natural delivery with varicose veins of the external genitalia and the perineum, to reduce the risk of bleeding in case of possible rupture of varicose nodes and by narrowing the indications to surgical delivery; in 26 patients (10.16 \%), according to their wishes, the reduction of cosmetic problems caused by varicose veins of the external genitalia and / or on the open parts of the lower extremities. All operated pregnant women were performed duplex scans of veins with cartography of pathological zones (refluxes, varicose conglomerates), cardiotocography (CTG), fetometry (FM), both before and after surgery.

Results and Discussion. The surgical interventions were performed only with the consent of the pregnant women, in the absence of any contraindications to surgical intervention, both from the somatic and obstetric statuses in the conditions of the obstetrical in-patient department. All surgical interventions were carried out without premedication, tumescence anesthesia and surgical technique by CHIVA type were used with the downward development of PSCVD, and with the ascending - combination of CHIVA and ASVAL techniques. In $100 \%$ of pregnant women during surgery, in the postoperative period violations of the somatic status, uterine tone in pregnant women, the heartbeat of the fetus (data of CTG, FM) have not been recorded. According to the subjective evaluation by pregnant women, violations of the quantity and quality of fetal movements have not been noted and they noted in $98 \%$ of cases the positive clinical outcome of surgical intervention. Operated in the II-nd and at the beginning of the III-rd trimesters, $85 \%$ were within 24 hours, $10 \%$ for 48 hours in the hospital, after that they were discharged under supervision of obstetrician-gynecologist by place of residence, $5 \%$ of operated persons at the end of the III-rd trimester stayed in the hospital until childbirth.
\end{abstract}

Key words: surgical treatment during pregnancy; safety of surgical intervention during pregnancy; assessment of pain syndrome; ts-VAS scale. 
В. М. АНТОНЮК-КИСЕЛЬ ${ }^{1}$, И. Я. ДЗЮБАНОВСКИЙ, В. М. ЕНИКЕЕВА ${ }^{1}$, С. И. ЛИЧНЕР ${ }^{1}$, В. М. ЛИПНЫЙ H. B. CEMEHЮК ${ }^{3}$

КУ "Областной перинатальный центр" Ровенского областного совета ${ }^{1}$

ГВУЗ “Тернопольский государственный медицинский университет имени И. Я. Горбачевского МЗ Украины”"2

ООО “ЛОКЕ”, РОВНО

\title{
ПОКАЗАНИЯ К ПЛАНОВОМУ ХИРУРГИЧЕСКОМУ ЛЕЧЕНИЮ БЕРЕМЕННЫХ ПРИ ПЕРВИЧНОМ РЕЦИДИВИРУЮЩЕМ ХРОНИЧЕСКОМ ЗАБОЛЕВАНИИ ВЕН НИЖНИХ КОНЕЧНОСТЕЙ, НАРУЖНЫХ ПОЛОВЫХ ОРГАНОВ, ПРОМЕЖНОСТИ ИЛИ В ИХ СОЧЕТАНИИ В УС.ЛОВИЯХ КРАТКОСРОЧНОГО ПРЕБЫВАНИЯ В СТАЦИОНАРЕ
}

\begin{abstract}
Цель работы: разработать и внедрить строго индивидуальные показания к безопасному как для матери, так и ребенка, эффективному патогенетическому плановому хирургическому лечению беременных с первичным симптоматическим хроническим заболеванием вен (ПСХЗВ) в условиях краткосрочного пребывания в акушерском стационаре (до 72 ч по терминологии IAAS).

Материалы и методы. На базе коммунального учреждения “Областной перинатальный центр” Ровенского областного совета за период с начала 2013 г. по первый квартал 2018 г. прооперировано 256 беременных с ПСХ3В C2S-C4s, EP,As,p.Pr (basis CEAP, 2002). Показаниями к плановому оперативному вмешательству являются: у 196 беременных (76,56 \%) - нарастание явлений хронической венозной недостаточности нижних конечностей, наружных половых органов, промежности несмотря на проводимую консервативную терапию, у 34 пациенток (13,28 \%) с целью подготовки родовых путей к естественным родам при варикозном расширении вен наружных половых органов и промежности, для уменьшения рисков кровотечений при возможном разрыве варикозных узлов и сужая показания к хирургическим родам; у 26 больных $(10,16$ \%) по их желанию уменьшение косметических проблем, обусловленных варикозным расширением вен наружных половых органов и/или на открытых участках нижних конечностей. Всем оперированным беременным выполнено дуплексное сканирование вен с картографированием патологических зон (рефлюксы, варикозные конгломераты), кардиотокографии (КТГ), фетометрии (ФМ) как до, так и после операции.

Результаты исследований и их обсуждение. Оперативные вмешательства выполняли только при согласии беременных, при отсутствии противопоказаний к оперативному вмешательству как со стороны соматического, так и акушерского статуса в условиях акушерского стационара. Все оперативные вмешательства выполнялись без премедикации, использовали для обезболивания тумесцентную анестезию и хирургическую методику по типу CHIVA при нисходящем развитии ПСХЗВ, а при восходящем - сочетание методик CHIVA и ASVAL. У 100 \% беременных во время оперативного вмешательства, в послеоперационном периоде нарушений соматического статуса, тонуса матки у беременных, сердцебиения плода (данные КТГ, $\Phi М)$ не зафиксировано. По субъективной оценке беременными нарушений количества и качества движений плода не отмечено и ими же отмечено в 98 \% случаев положительный клинический результат хирургического вмешательства. Оперированные в II и в начале III триместров у 85 \% находились в течение 24 ч, $10 \%$ - в течение 48 ч в условиях стационара, после выписывались под наблюдение акушера-гинеколога по месту жительства, 5 \% оперированных в конце III триместра оставались в стационаре до родов.
\end{abstract}

Ключевые слова: хирургическое лечение во время беременности; безопасность оперативного вмешательства во время беременности; оценка болевого синдрома; ц-ВАШ шкала. 